\title{
EDITORIAL
}

\section{Understanding Fish Populations}

In 2017, the Fisheries Society of the British Isles (FSBI) celebrated its 50th Anniversary and to celebrate this landmark occasion its Council supported the sponsorship of a special Anniversary Symposium. This corresponding Special Issue of the Journal of Fish Biology contains a selection of papers presented at that meeting, and we hope gives a flavour of the diversity and dynamism that characterised it.

The FSBI was founded in 1967 by prominent fish biologists Jack Jones, David Le Cren, Lionel Mawdesley-Thomas, Alwynne Wheeler and angling journalist Peter Tombleson, who had all been regular attendees at the annual 'Coarse Fish Conferences' held at the University of Liverpool during the mid 1960s. The FSBI began its own venture into holding scientific meetings with day-long symposia interspersed with occasional larger international meetings, and by the mid-1980s an annual international symposium had become a major focus of the FSBI's year. Over the intervening years these FSBI-sponsored symposia have provided many opportunities to bring together scientists from around the globe to discuss, in depth, a wide range of timely and important topics in fish biology and fisheries science. These symposia have recently covered themes as specialised and diverse as the biology of deep sea fish and the evolution and behaviour of sticklebacks, through to the parasitology of fish and the ecology and conservation of elasmobranchs, as well as including more general conferences focusing on fish genes and genomes and the impacts of climate change.

There are many complementary reasons why the global scientific community endeavours to understand the biology and ecology of fishes, and the factors that influence fish populations. Fish represent more than half of all the vertebrate species on the planet, and they are found in almost all marine, brackish and freshwater environments throughout the world. Thus, they make ideal focal taxa for understanding past and contemporary patterns in biogeography and biodiversity, and are valuable models for exploring the processes of speciation and adaptive evolution. A product of their remarkable diversity is the staggering range of behaviours and life history strategies that they exhibit, providing behavioural ecologists with seemingly limitless opportunities to drill into sensory, reproductive, foraging, territorial and predator-prey ecology in aquaria, mesocosms and in natural settings. Since fish often live in complex and resource-limited environments, and are usually found in multi-species assemblages, they allow trophic and functional ecologists to develop and test theories in situ and with large scale manipulations.

However, we live in an era of rapid environmental change, much of it human-induced. Local, present-day stressors including fishing, chemical pollution, eutrophication, habitat modification, plastics and noise which all challenge key biological processes that can affect individual fitness. Extrapolating from, often, small-scale controlled aquaria experiments on individual stressors to build generalised predictions of population-level consequences is non-trivial, but is key for developing appropriate management advice and practice. Global, present and future stressors are also of 
growing concern, with global warming changing species distributions and phenology, ocean acidification compromising sensory and cognitive behaviour, and lower oxygen environments challenging physiological processes and population characteristics. Yet in spite of the growing number of threats faced by fish populations across the globe, hundreds of millions of people depend on healthy fish populations for dietary protein, and the economies of communities, regions and entire countries can depend on fish populations for food and financial security. Managing fish for food, ecosystem health, recreation and conservation in the 21st century requires a holistic understanding of fish populations, and multi-disciplinary, international, integrative collaboration is required.

Based on this rationale, the organisers decided that the 50th Anniversary Symposium of the FSBI should have a wide remit, bringing fish and fisheries scientists together from across the entire fish biology and fisheries science community and also reaching beyond the current FSBI membership. The theme of Understanding Fish Populations was chosen, and proved to be successful in attracting a large, diverse and highly international audience. During a sunny week in July 2017, over 215 participants from 27 countries, including 65 postgraduate students and a high proportion of early career researchers, came together for five days at the University of Exeter, U.K., to exchange knowledge, strengthen research networks and share expertise through 233 presentations, deepening the collective understanding of fish populations across the community.

During the symposium, as many presentations were given by non-U.K.-based as by U.K.-based researchers, and the international flavour was reinforced with exceptional invited keynote addresses from Joanna Alfaro (Peru), Isabelle Côté (Canada), William Cheung (Canada), lain Couzin (Germany), Beth Fulton (Australia) and Peter Mumby (Australia), and from Charles Tyler (U.K.), who delivered the Jack Jones lecture. The international diversity that was so evident at the symposium, and the geographical breadth of the species, ecosystems and habitat types covered in the presentations, serves as a timely reminder of the global reach of the work undertaken by the community served by the FSBI and the Journal of Fish Biology. It also emphasises the importance of maintaining an outward-looking perspective in fish and fisheries research.

The papers presented in this Special Issue of the Journal of Fish Biology illustrate the diversity and quality of the presentations enjoyed through the symposium. All five of the symposium's session themes, i.e. Biology of Fish, Tools for Understanding Fish Populations, Fish in a Changing World, Valuing and Managing Fish Populations and Celebrating 50 years of the FSBI, are represented. In addition, and in a new departure for this symposium series, all of the themes are also addressed here in a series of discussion papers arising from workshops held during the symposium and written immediately afterwards by newly-forged assemblies of co-authors. These papers present the outcomes of a series of stimulating discussions held during the week on key topics and they outline challenges ahead for understanding fish populations, and we hope that these will help others identify key research areas for the future.

Unsurprisingly, Biology of Fish proved to be the dominant theme with Armstrong et al. (2018), Gregory et al. (2018) and Thomson \& Lyndon (2018) all addressing the perpetually fascinating topic 
of the life histories of migratory salmonids through studies making the most of state-of-the-art tagging technology applied to Atlantic salmon Salmo salar L. 1758, long-term data sets on individual S. salar, and the remarkable natural laboratory inhabited by the brown trout Salmo trutta L. 1758 populations of Orkney, U.K., respectively. Salmo salar was also the focus of studies of population genetics undertaken at the landscape scale by Cauwelier et al. (2018) and Ikediashi et al. (2018) in north-east and southern U.K., respectively, while $S$. trutta was also used as a model species by Arevalo et al. (2018) to investigate experimentally the likely effects of climate change on young salmonids. Representation of this session theme is completed by an elegant experimental study of welfare management for the widespread laboratory model species zebrafish Danio rerio (Hamilton 1822) performed by Lee et al. (2018) and an extensive and authoritative review by Côté \& Smith (2018) of over 150 studies addressing the remarkable invasion ecology of the Indo-Pacific lionfish Pterosis sp. The challenges and opportunities facing fish biology were considered by the discussion paper of Jacobs et al. (2018) using a framework of five key knowledge gaps comprising the use of fish biology to inform aquaculture and wild fisheries to address food security, the use of evolutionary biology to predict contemporary responses to stressors, the use of correlated traits to improve predictions of responses to environmental change, the use of existing datasets and new analytical approaches to gain novel insights, and the use of animal collective behaviour to understand better the group level impacts of environmental stressors.

Salmonids in the form of S. salar reappeared again within the theme of Tools for Understanding Fish Populations as the study species in a genetics-based investigation of the feasibility of estimating the effective number of adult breeders from single samples of young individuals reported by Bacles et al. (2018), with the discussion paper of Paris et al. (2018) addressing the wider subject under five main approaches of tagging and telemetry, molecular tools, survey tools, statistical and modelling tools, and tissue analyses. Fish in a Changing World is represented by specific and more generic studies. Specifically, the effects of increasing hypoxia on bearded goby Sufflogobius bibarbatus (von Bonde 1923) by Salvanes \& Gibbons (2018) and of the endocrine profiles of group-living skunk anemonefish Amphiprion akallopisos Bleeker [P.] 1853 by Mills et al. (2018) to improve our understanding of how species reproduction will be affected by future environmental changes. On a more generic level, the future of fishes and fisheries in the changing oceans was highlighted by Cheung (2018) and addressed by Gordon et al. (2018) in a wide-ranging discussion paper also including freshwater issues. Valuing and Managing Fish Populations is represented by the discussion paper of Obregon et al. (2018) which considered the eight key questions of the ecocentric values of fishes, the relation between human well-being and the contact with wild fish populations, the value of recreational fishing, the value of fish traded for consumption, how we can work towards equitable access to fisheries resources, the gaps in involvement and representation of women in valuing and managing fish and fisheries, the importance of recognising and safeguarding the genetic diversity of wild fishes, and increasing the value of scientific research through informing fish populations and fisheries management.

Finally, the theme of Celebrating 50 years of the FSBI is exemplified in a global context by a review by Lyndon (2018) of the impact of the FSBI Small Research Grants Scheme which has now been running for 25 years and has distributed over $£ 560,000$ to researchers around the world, and in more specific terms by an impressive argument presented by Pinnegar (2018) for why the Mediterranean damselfish Chromis chromis (L. 1758) is a key species in the Mediterranean rocky intertidal. This final paper is particularly fitting and satisfying because as was explained in more 
detail during its presentation at the symposium, this extensive chain of research was primarily initiated by the award in 1996 of a PhD Studentship to its author who has subsequently served on FSBI Council, including as Honorary Secretary, and is currently a co-convenor of FSBI's next symposium in 2018.

We are grateful to the many anonymous reviewers whose time and expertise were freely given to improve further the outstanding papers presented in this Special Issue, and we would also like to thank the outgoing Editor-in-Chief of the Journal of Fish Biology John Craig and Managing Editor Hilary Craig for their guidance and work on this issue. We also extend our gratitude to the FSBI for generous sponsorship of the symposium, which allowed the organisers to offer 34 bursaries for visiting postgraduates from 15 countries, and to the FSBI Council for their enthusiastic support over the year leading up to the symposium. We would also like to acknowledge generous sponsorship from Wiley Publishers, APEM, Sole of Discretion, Geospectrum, Star:Oddi, Vemco, Young's Seafood and Physalia Courses. The symposium would not have been possible without excellent professional support from Event Exeter. With a meeting of this size and breadth, managing the abstracts and developing an exciting programme would similarly not have been possible without the valuable input, often with very challenging deadlines, of our International Scientific Advisory Committee: John Armstrong, lain Barber, Safi Darden, Jennifer Fitzgerald, Martin Genner, Alistair Lyndon, Neil Metcalfe, Sophie Nedelec, John Pinnegar, Eduarda Santos, Steve Simpson, Jamie Stevens, Rachel Turner, Rod Wilson and lan Winfield. The structure for each day and range of social activities were the result of some valuable early discussions with the Local Organising Committee: Darren Croft, Safi Darden, Brendan Godley, Andrew Griffiths, Tetsu Kudoh, Eduarda Santos, Steve Simpson, Jamie Stevens, Rachel Turner and Rod Wilson. Logistical operations, AV and tech support, photography, running of the registration desk and participant management were all made possible by the enthusiastic support of University of Exeter postgraduate students: Will Corbett, Isla Davidson, Will Davison, Rob Ellis, Pandora Godfrey, Tim Gordon, Harry Harding, Luke Hooper, Dan Montgomery, Sulayman Mourabit, Josie Paris, Louise Rutterford, Nigel Sainsbury, Krista Sherman, Emma Weschke and Guy Whittaker. Finally, we would like to thank the excellent Plenary Speakers and $>200$ Oral Talk, Speed Talk and Poster presenters for making the 50th Anniversary Symposium a wonderfully memorable week.

\section{S. D. SIMPSON}

Biosciences, College of Life and Environmental Sciences, Geoffrey Pope, Stocker Road, Exeter, Dorset EX4 4QD, U.K.

\section{BARBER}

School of Animal, Rural and Environmental Sciences, Nottingham Trent University, Brackenhurst Campus, Southwell, Nottinghamshire NG25 OQF, U.K.

\section{J. WINFIELD}

Lake Ecosystems Group, Centre for Ecology \& Hydrology, Lancaster Environment Centre, Library Avenue, Bailrigg, Lancaster, Lancashire LA1 4AP, U.K. 


\section{References}

Arevalo, E., Panserat, S., Seiliez, I., Larrañaga, A. \& Bardonnet, A. (2018). Effect of food shortage and temperature on age $0+$ years salmonids: A contribution to predict the effects of climate change. Journal of Fish Biology (this issue).

Armstrong, J. D., McKelvey, S., Smith, G. W., Rycroft, P. \& Fryer, R. J. (2018). Effects of individual variation in length, condition and run-time on return rates of wild-reared Atlantic salmon Salmo salar smolts. Journal of Fish Biology (this issue).

Bacles, C. F. E., Bouchard, C., Lange, F., Manicki, A., Tentelier, C. \& Lepais, O. (2018). Estimating the effective number of breeders from single parr samples for conservation monitoring of wild populations of Atlantic salmon Salmo salar. Journal of Fish Biology (this issue).

Cauwelier, E., Stewart, D. C., Millar, C. P., Gilbey, J. \& Middlemas, S. J. (2018). Across rather than between river genetic structure in Atlantic salmon Salmo salar in north-east Scotland, UK: Potential causes and management implications. Journal of Fish Biology (this issue).

Cheung, W. W. L. (2018). The future of fishes and fisheries in the changing seas. Journal of Fish Biology (this issue).

Côté, I. M. \& Smith, N. S. (2018). The lionfish Pterois sp. invasion: Has the worst-case scenario come to pass? Journal of Fish Biology (this issue).

Gordon, T. A. C., Harding, H. R., Clever, F. K., Davidson, I. K., Davison, W., Montgomery, D. W., Weatherhead, R. C., Windsor, F. M., Armstrong, J. D., Bardonnet, A., Bergman, E., Britton, J. R., Côté , I. M., D’Agostino, D., Greenberg, L. A., Harborne, A. R., Kahilainen, K. K., Metcalfe, N. B., Mills, S. C., Milner, N. J., Mittermayer, F. H., Montorio, L., Nedelec, S. L., Prokkola, J. M., Rutterford, L. A., Salvanes, A. G. V., Simpson, S. D., Vainikka, A., Pinnegar, J. K. \& Santos, E. M. (2018). Fishes in a changing world: learning from the past to promote sustainability of fish populations. Journal of Fish Biology (this issue).

Gregory, S. D., Armstrong, J. D. \& Britton, J. R. (2018). Is bigger really better? Towards improved models for testing how Atlantic salmon Salmo salar smolt size affects marine survival. Journal of Fish Biology (this issue). 
Ikediashi, C., Paris, J. R., King, R. A., Beaumont, W. R. C., Ibbotson, A. \& Stevens, J. R. (2018). Atlantic salmon Salmo salar in the chalk streams of England are genetically unique. Journal of Fish Biology (this issue).

Jacobs, A., Doran, C., Murray, D. S., Duffill Telsnig, J., Laskowski, K. L., Jones, N. A. R., Auer, S. K. \& Praebel, K. (2018). On the challenges and opportunities facing fish biology: a discussion of five key knowledge gaps. Journal of Fish Biology (this issue).

Lee, C. J., Tyler, C. R. \& Paull, G. C. (2018). Can simple tank changes benefit the welfare of laboratory zebrafish Danio rerio? Journal of Fish Biology (this issue).

Lyndon, A. R. (2018). Impact of the FSBI Small Research Grants scheme: an analysis and appraisal. Journal of Fish Biology (this issue).

Mills, S. C., O'Donnell, J., Bernardi, G. \& Beldade, R. (2018). Natural endocrine profiles of the groupliving skunk anemonefish Amphiprion akallopisos in relation to their size-based dominance hierarchy. Journal of Fish Biology (this issue).

Obregón, C., Lyndon, A. R., Barker, J., Christiansen, H., Godley, B. J., Kurland, S., Piccolo, J. J., Potts, R., Short, R., Tebb, A. \& Mariani, S. (2018). Valuing and understanding fish populations in the Anthropocene: key questions to address. Journal of Fish Biology (this issue).

Paris, J. R., Sherman, K. D., Bell, E., Boulenger, C., Delord, C., El-Mahdi, M. B. M., Fairfield, E. A., Griffiths, A. M., Gutman Roberts, C., Hedger, R. D., Holman, L. E., Hooper, L. H., Humphries, N. E., Katsiadaki, I., King, R. A., Lemopoulos, A., Payne, C. J., Peirson, G., Richter, K. K., Taylor, M. I., Trueman, C. N., Hayden, B. \& Stevens, J. R. (2018). Understanding and managing fish populations: keeping the toolbox fit for purpose. Journal of Fish Biology (this issue).

Pinnegar, J. K. (2018). Why the damselfish Chromis chromis is a key species in the Mediterranean rocky littoral: a quantitative perspective. Journal of Fish Biology (this issue).

Salvanes, A. G. V. \& Gibbons, M. J. (2018) Adaptation to hypoxic environments: bearded gobies Sufflogobius bibarbatus in the Benguela upwelling ecosystem. Journal of Fish Biology (this issue).

Thomson, M. \& Lyndon, A. R. (2018). Comparing anadromous brown trout Salmo trutta in small, neighbouring catchments across contrasting landscapes: what is the role of environment in determining life-history characteristics? Journal of Fish Biology (this issue). 